International Journal of Advanced Studies in Humanities and Social Science (IJASHSS)

Available online at http://www.ijashssjournal.com

Volume 9, Issue 1 (2020) pp. 21-36

DOI:10.33945/SAMI/IJASHSS.2020.1.2

Original Article

\title{
The Relationship between Mission Statement and Firms' Performance
}

\section{Sajjad Salehi-Kordabadi ${ }^{*}$, Sajjad Karimi², Mohammad Qorbani-Azar ${ }^{3}$}

${ }^{1}$ Department of Public Management, Faculty of Management and Economics, , Islamic Azad

University Science and Research Branch, Tehran, Iran

2Department of Management, Faculty of Management and Economics, Islamic Azad University, Dehaghan, Iran

3 Department of Management, Faculty of Management and Accounting, Islamic Azad University, Rasht, Iran

*Corresponding Author E-mail: S_Salehi@srbiau.ac.ir

Received: 19 January 2020, Revised: 22 February 2020, Accepted: 24 March 2020

\begin{abstract}
After two decades of research, the clear relationship between a mission statement and a firm's performance is not found yet. Past research has demonstrated the meaningful relationship between the mission statement and the performance. Some of these studies, however, have indicated there is no meaningful relationship between the mission statement and the performance. The aim of this paper is to identify the relationship between the mission statement components and the performance components. Moreover, it tries to help managers to state high quality of the mission statement in their firms. Six-component mission statement was developed to measure the completeness of firm's mission statement, and the BSC was used so as to measure the firms' performance. The BSC includes four dimensions: financial, customer, internal process and learning and growth. In this research, field research technique was applied, and questionnaires were used in order to gather data. The statistical population was 35 firms. Totally, 1400 questionnaires were passed out, 40 questionnaires in each firm, out of which 1230 questionnaires were returned. SPSS 18 was utilized to analyze the data. Results indicated a significant positive relationship between the components of the mission statement and some of the performance components. The most significant positive relationship was found between the purpose and the financial component, and the least significant positive relationship was found between the vision and the internal presses. In addition, the financial dimension was related to the all the mission components. As a result, improving j7biscmxi8firm mission statement will improve financial performance, and strategic managers should devote extreme attention to this issue.
\end{abstract}

Keywords: Mission Statement, Firm Performance, BSC. 


\section{Introduction}

Representing the firm ultimate aims, the mission statement usually includes a sentence about the reasons of the firm existence (Bryson and Altson, 2005). The mission statement is one of the most important and fundamental characteristics of the highest performance firms (Collins and Porras, 1997). Mission statement determines criteria to measure achievement in a firm's aims (Bryson and Altson, 2005). Developing a consensus on the aim in all levels of the firm, the mission statement develops a synergy under a current slogan in the firms by set of values in line with firm's aims. In addition, the mission statement provides employers with understanding about the firm's macro and micro aims (Campbell et al., 2001). It leads to either an increase in the commitment or the performance improvement (Toftoy and Chatterjee, 2004). Many studies have examined the relationship between a mission statement and a firm's performance. Such studies can fall into two categories: in the first category, no significant relationship between a mission statement and a performance has been reported, including Bart's study. He says there exists no empirical evidence to support relationship between a mission statement and a firm's performance. In addition, Hahn and Powers (1999) says a mission statement has no effect on the firm's performance. In second category, studies are indicative of the positive relationship between a mission statement and firm's performance. Bart and Hupfer (2004) indicate that there is a positive relationship between a mission statement and a firm's performance. Moreover, Green and Medlin (2003) found a positive meaningful relationship between a mission statement and a firm's performance. Desmidt et al.
(2011) found a weak relationship between the mission statement and the firm's performance in industrial firms. This article aimed at identifying the relationship between the mission statement components and the firm's performance dimensions. In mission statement, Green and Medlin (2003) used mission model developed by Wheelen and hungers (2000). This model includes two components: purpose and vision. Green and Medlin (2003) concluded the relation among variables was weak, and it should be used other independent variables should be used. For this reason, these model components were expanded. In firm's performance, the BSC was used for performance evaluation.

\section{Literature Review}

\section{Mission statement}

There is no doubt that the mission statement is one of the important parts in strategic planning process. Being indication of firm purpose, the mission statement is determining firm's aims. Furthermore, the mission statement includes guidance values in firms. Because, in case firm have aims that never include purpose and value, the firm cannot provide necessary resources (Barnes, 1987). Pearce (1982) holds that the mission statement represents direction for managers that is shared by employers' expectations. Bart and Tabone (1998) and Drohan (1999) state a mission statement shows the intent and purpose of firms Not only does mission statement show whatever is done in firms, but also it is a guideline for things not performed in firms (Alison and Kaye, 2005). As a result, beliefs expression, purpose expression, philosophy expression, principle 
expression, vision expression, and the mission statement relate to philosophy and vision in the future of firms. Following are reasons for the mission statement importance: 1. A mission statement provides the basis for resources allocation in firms; 2. A mission statement provides the focal point for managers for an effort aimed at firms; 3. A mission statement provides a framework for aims and plans implement; 4. It can help employers to understand the firm aims and the framework for the decision-making process; 5 . Shareholders are supported by the mission statement; 6 . The focus of the employers attempt is helped in the defined direction, and the mission statement causes the values and exceptions to be shared by all the employers; 7 . The value creation emerges that shows the image of the firm among people out of the firm (Haghighy et al., 2010). Firms' Mission statements are different in Size, content, form, and details. Therefore, each of the strategic management experts state the variety of components in a mission statement. Green and Medlin (2003) used the model that was designed by Wheelen and Hungers (2000). This model includes two main components of purpose and vision. Green and Medlin (2003) concluded that there is relative weakness of the relationship among variables. Therefore, other independent variables should be considered. In this regard, four components were added. Finally, model was designed that includes the six main components as figure1.

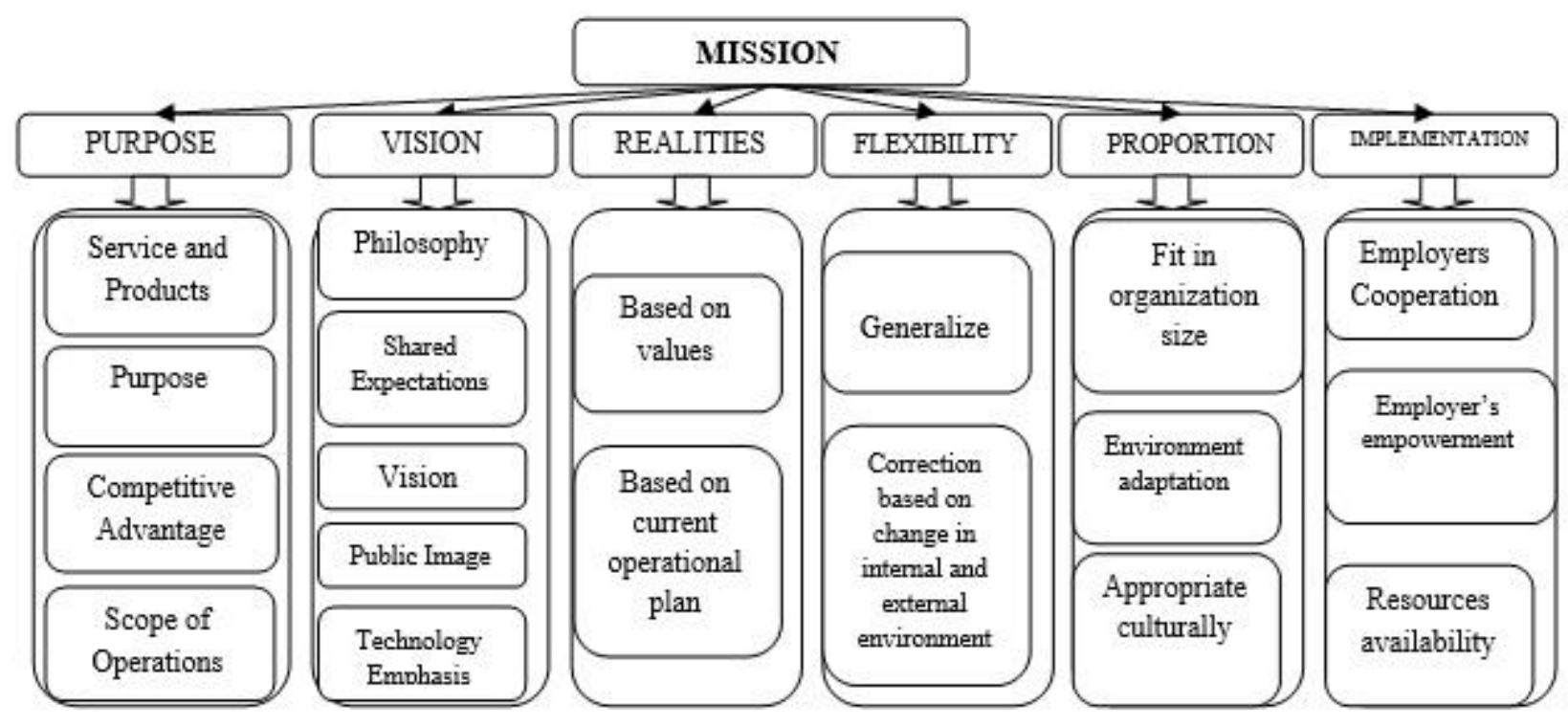

Figure 1. Model of mission

\section{Performance evaluation}

As the process of quantifies efficiency and operations effectiveness, performance evaluation divides into 3 main parts: 1 . Strategic aims including strategic management and strategic review; 2 . Communication aims including control of current situation; 3. Motivation aims including development of a reward system and learning encouragement (Wing et al., 2007). Traditionally, the information of firms is used for the performance evaluation to provide the information needed to evaluate the performance which is difficult in the public organizations. When the 
information of firms cannot be gained, the performance evaluation is carried out under manager's mind (Allen and Helms, 2002). In the past, the performance evaluation was carried out following financial indicators (Wing et al., 2006). In the past two decades, the indicators received attention for the determinant factors of the competitive advantages such as formal learning, Knowledge creation and innovation capacity (Crossan and Bedrow, 2003). Many models have been designed for performance evaluation. Some models are time-andcost based that focuse on financial assessment and production process such as Score model. Self-assessment models focuse on management field and production process based on outcome and quality process improvement. Deming model, the ISO model, the Baldrige model, the EFQM model fall in this category. There are models that focus on evaluation criteria in the management field, production process, operation, financial, and human resource based on strategic implication and improvement like. It can be cited the SMART model, the Benchmarking model, the MBO model, the
HOSHIN model, and the BSC model. In this paper BSC model was used for the performance evaluation. BSC characteristics are continuous assessment, cause and effect relationship establishment, creative spirit rise, cooperation climate, leading indicator, lagging Indicators, emphasis on learning, emphasis on product outcome, emphasis on performance and strategy adaptation, emphasis on strategy comprehension, emphasis on process performance. Firstly, the BSC had been measure and performance management. Next, this instrument was used for strategy implication, and nowadays the BSC $\mathrm{a}$ is strategic management system. Kaplan and Norton (2001) found that not only do successful firms care for financial dimensions, but also, they care for customer dimensions, internal process dimensions, learning and growth dimensions as the BSC indicators. What follows are explanations of the four dimensionss:

Financial dimensions: what service is offered efficiency and effectiveness, and what our financial stakeholders expect or demand (Niven, 2008).

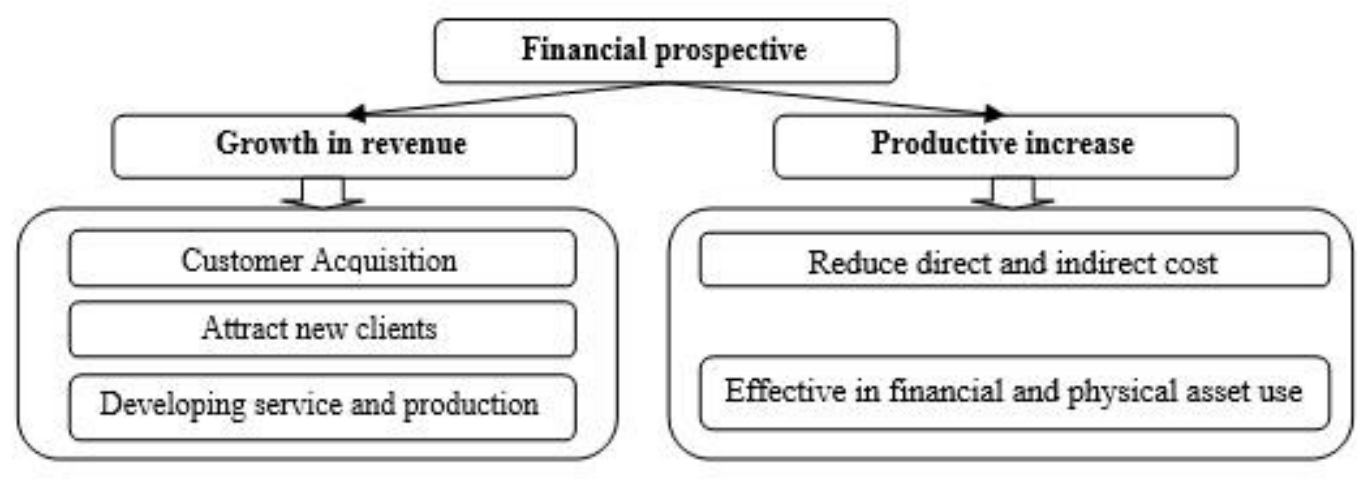

Figure 2. Model of financial dimensions Customer dimensions: the main factor in the performance enhancement is the aim to attract customers successfully and who our target customers are, what their expectations are, and what is our value

proposition in strategic them (Niven, 2008).

Internal process dimensions: the customer dominant values are fostered by internal process. The internal process performance 
is a leading indicator that shows what business processes must we excel to drive value for customer (Niven, 2008).

Learning and growth dimensions: The intangible assets are resources for truly values creation. The learning and growth describe that how we align our intangible assets to improve our ability out support our strategy (Niven, 2008).

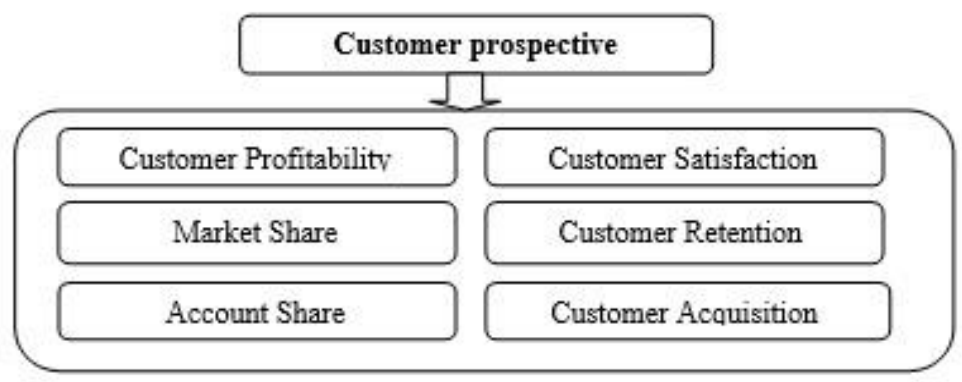

Figure 3. Customer dimensions

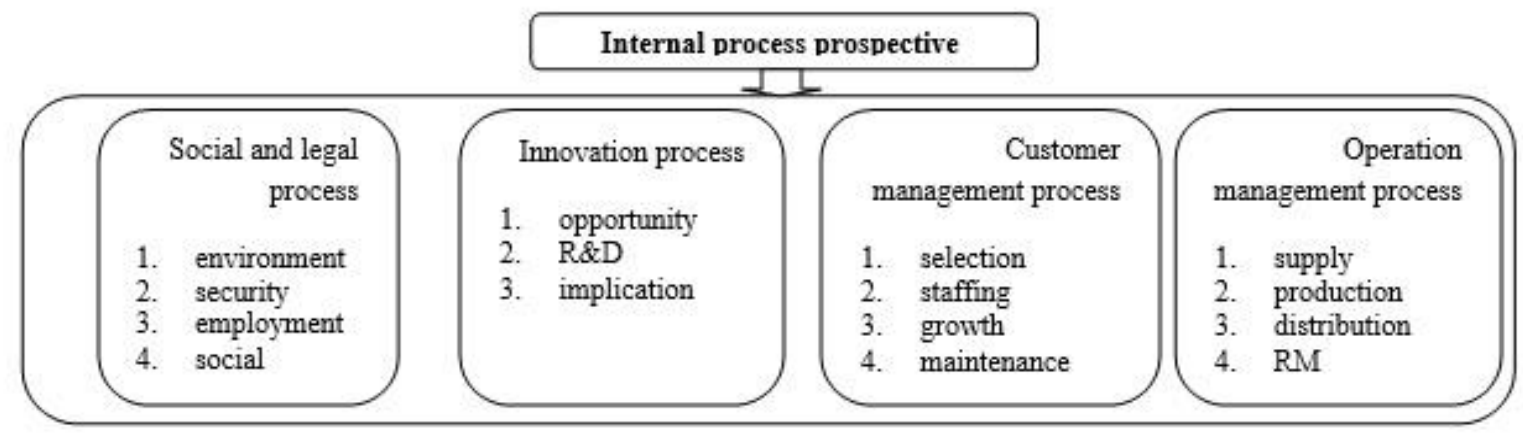

Figure 4. Internal process dimensions

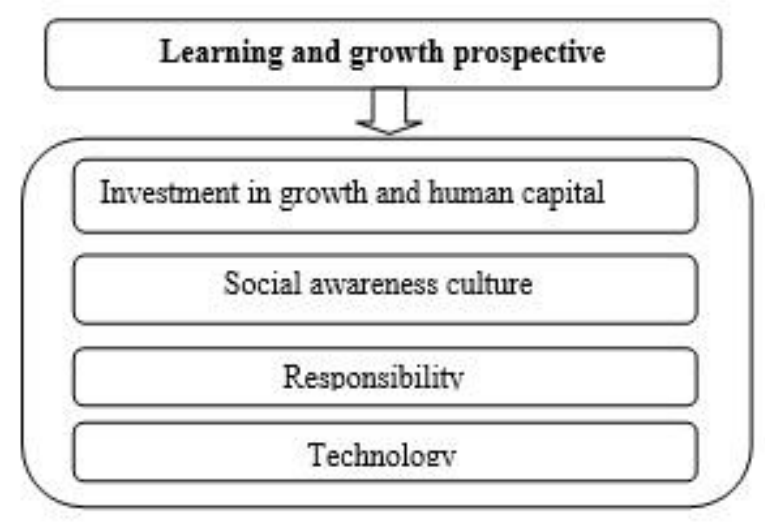

Figure 5. Learning and growth dimensions

Mission statement and performance evaluation

In past two decades, the researchers studied a relationship between a mission statement and a firm's performance. No meaningful difference was found in firms performance based on the mission statement research in the fifty-nine large firms in Times magazine (Klemm et al., 1991). Wilson (1992) says that the existence of a mission statement has no guarantee for firms' success; the lack of 
mission statement, however, has no guarantee for firms' bankruptcy. The existence of the philosophy in a mission statement does not lead to performance improvement (Egormen and Doran, 1999). Baret (1998) found the positive relationship between the firm's performance and the mission statement. In addition, he maintained that the specific component in a mission statement has finance effect on a firm's performance. Analoui and Karami (2002) concluded the high-performance firms are of less complete mission statement than lowperformance firms. Green and Medlin (2003) found a link between the completeness and quality of the firm's mission statement and the firm's financial performance. Desmidt et al., (2011) found a small positive relation between a mission statement and a measure of financial formal performance. Because the results of the previous studies are unclear, it is necessary to further investigate the link between mission and performance. This paper probed into the relationship between the components of mission statement and the performance in firms in which development of BSC strategy was investigated. In this paper, the mission statement includes six components including: 1. Purpose; 2. Vision; 3. Realities; 4. Flexibility; 5. Proportion; and 6. Implementation. Performance evaluation was used from BSC that includes:1. Financial dimensions; 2. Customer dimensions; 3. Internal process customer; 4. Learning and growth dimensions. Hypotheses based on the relationship among the mission statement components and the BSC perspectives are as follows:

1) Purpose: the purpose components are comprised of four items: 1) firm purpose; 2) firm product; service and markets; 3) firm competitive advantage and 4) the firm's scope of operations.

1-1) There is a meaningful relationship between purpose and financial dimensions.

1-2) There is a meaningful relationship between purpose and customer dimensions.

1-3) There is a meaningful relationship between purpose and internal process dimensions.

1-4) There is a meaningful relationship between purpose and learning and growth dimensions.

2) The vision components are comprised of five items: 1) firm philosophy; 2) firm vision; 3) sense of shared expectations; 4) positive public image; and 5) emphasis on technology, creativity and innovation.

2-1) There is a meaningful relationship between vision and financial dimensions.

2-2) There is a meaningful relationship between vision and customer dimensions.

2-3) There is a meaningful relationship between vision and internal process dimensions.

2-4) There is a meaningful relationship between vision and learning and growth dimensions.

3) The realities components are comprised of five items: 1) based on values; 2) based on current operational plan.

3-1) There is a meaningful relationship between realities and financial dimensions.

3-2) There is a meaningful relationship between realities and customer dimensions.

3-3) There is a meaningful relationship between realities and internal process dimensions. 
3-4) There is a meaningful relationship between realities and learning and growth dimensions.

4) The flexibility components are comprised of these items: 1) generalization; 2) correction based on change in internal and external environment

4-2) There is a meaningful relationship between flexibility and financial dimensions.

4-2) There is a meaningful relationship between flexibility and customer dimensions.

4-3) There is a meaningful relationship between flexibility and internal process dimensions.

4-4) There is a meaningful relationship between flexibility and learning and growth dimensions.

5) The proportion components are comprised of five items: 1) fit in firm size; 2) environment adaptation; 3) cultural appropriateness .

5-1) There is a meaningful relationship between proportion and financial dimensions

5-2) There is a meaningful relationship between proportion and customer dimensions

5-3) There is a meaningful relationship between proportion and internal process dimensions

5-4) There is a meaningful relationship between proportion and learning and growth dimensions.

Table1. Cronbach's $\alpha$ Scores
6) The implementation component is comprised of five items: 1) employers' cooperation; 2) employer's empowerment; 3 ) resources availability

6-1) There is a meaningful relationship between implementation and Financial dimensions.

6-2) There is a meaningful relationship between implementation and Customer dimensions.

6-3) There is a meaningful relationship between implementation and Internal process dimensions.

There is a meaningful relationship between implementation and Learning and growth dimensions.

\section{Research method}

This study is a descriptive survey research attempt. . Questionnaire in this study was the main tool for data collection. Data collection tools in this study were two separate questionnaires for assessing the missions' statement and the firms' performance: Mission statement questionnaire designed by Green and Medlin (2003) and mission statement questionnaire by Bart and Hupfer (2004) that include 19 questions. The firms' performance questionnaire was used the BSC indexes based on Agostino and Arnaboldi (2011) which includes 30 questions. The validity of the questionnaire was approved by the previous research. Furthermore, to test the questionnaires reliability we used Cronbach's $\alpha$ scores for each variable as shown in Table 1. 


\begin{tabular}{llll}
\hline Variables & Dimensions & $\begin{array}{l}\text { Number } \\
\text { items }\end{array}$ & of \\
& Purpose & 4 & 0.90 \\
Mission & Vision & 5 & 0.78 \\
statement & Realities & 2 & 0.81 \\
& Flexibility & 2 & 0.86 \\
& Proportion & 3 & 0.85 \\
& Implementation & 3 & 0.78 \\
& Total Dimensions & $\mathbf{1 9}$ & $\mathbf{0 . 8 3}$ \\
& Financial & 5 & 0.83 \\
Performance & Customer & 6 & 0.75 \\
& Internal Process & 15 & 0.79 \\
& Learning and Growth & 4 & 0.79 \\
& Total Dimensions & $\mathbf{3 0}$ & $\mathbf{0 . 7 9}$ \\
\hline
\end{tabular}

Statistical population and sample: The 1-2) There is a meaningful relationship statistical populations of this study were thirty-five of the firms in which BSC between purpose and customer perspective.

strategy was developed. Forty questionnaires were distributed in each firm. A total of 1400 of the questionnaires was distributed, and eventually 1230 questionnaires were returned and used for statistical analysis. Using SPSS 18, we computed correlation and regression As previously stated, we had these hypotheses:

1-1) There is a meaningful relationship between purpose and financial perspective. 1-3) There is a meaningful relationship between purpose and internal process perspective.

1-4) There is a meaningful relationship between purpose and learning and growth perspective.

Based on the above relations, the hypotheses were tested by Pearson correlation due attention to Table 2 .

Table2. Correlations test of section 1 hypotheses

\begin{tabular}{lll}
\hline & & Financial \\
\cline { 2 - 3 } & Pearson Correlation & $0.61^{* *}$ \\
Sig. (2-tailed) & 0.001 \\
& $\mathrm{~N}$ & 1230 \\
& Pearson Correlation & Customer \\
Sig. (2-tailed) & $0.49^{* *}$ \\
Purpose & 0.001 \\
& & 1230 \\
& Pearson Correlation & Internal process \\
& Sig. (2-tailed) & $0.41^{* *}$ \\
& N & 1230 \\
& & Learning and Growth \\
& Pearson Correlation & $0.26^{* *}$ \\
& Sig. (2-tailed) & 0.009 \\
& N & 1230 \\
& $* *$ indicate statistical significance at the .01 level \\
\hline
\end{tabular}

The results of statistical tests of these purpose and financial perspective, hypotheses (Table 2) indicate that there is customer perspective, internal process a significant relationship between the 
perspective, learning and growth perspective.

In the second section, we have these hypotheses:

2-1) There is a meaningful relationship between vision and financial perspective.

2-2) There is a meaningful relationship between vision and customer perspective.
2-3) There is a meaningful relationship between vision and internal process perspective.

2-4) There is a meaningful relationship between vision and learning and growth perspective.

Based on the above relations, the hypotheses were tested by Pearson correlation as shown in Table 3.

Table 3. Correlations test of section 2 hypotheses

\begin{tabular}{|c|c|c|}
\hline \multirow[t]{17}{*}{ Vision } & \multicolumn{2}{|r|}{ Financial } \\
\hline & Pearson Correlation & $0.41^{* *}$ \\
\hline & Sig. (2-tailed) & 0.000 \\
\hline & \multirow[t]{2}{*}{$\mathrm{N}$} & 1230 \\
\hline & & Customer \\
\hline & Pearson Correlation & $0.39 * *$ \\
\hline & Sig. (2-tailed) & 0.000 \\
\hline & \multirow[t]{2}{*}{$\mathrm{N}$} & 1230 \\
\hline & & Internal process \\
\hline & Pearson Correlation & $0.21^{* *}$ \\
\hline & Sig. (2-tailed) & 0.001 \\
\hline & \multirow[t]{2}{*}{$\mathrm{N}$} & 1230 \\
\hline & & Learning and growth \\
\hline & Pearson Correlation & $0.53^{* *}$ \\
\hline & Sig. (2-tailed) & 0.076 \\
\hline & $\mathrm{N}$ & 1230 \\
\hline & \multicolumn{2}{|c|}{$\begin{array}{l}* * \text { indicate statistical significance at the } .01 \\
\text { level }\end{array}$} \\
\hline
\end{tabular}

Based on the results of statistical tests (Table 3) we can say that there is a significant relationship between the vision and financial perspective, customer perspective, and internal process perspective. There is no significant relationship between the vision and learning and growth perspective.

In the third section, we have these hypotheses:

3-1) There is a meaningful relationship between realities and financial perspective.

3-2) There is a meaningful relationship between realities and customer perspective.

3-3) There is a meaningful relationship between realities and internal process perspective.
3-4) There is a meaningful relationship between realities and learning and growth perspective.

Based on the above relations, the hypotheses were tested by Pearson correlation as displayed in Table 4.

Based on the results of statistical tests (Table 4) we can say that there is a significant relationship between the realities and financial component. However, there is no significant relationship between the realities and other dimensionss of the performance (customer, internal process, learning and growth).

In the fourth section, we had these hypotheses:

4-1) There is a meaningful relationship between flexibility and financial perspective.

4-2) There is a meaningful relationship between flexibility and customer perspective. 
4-3) There is a meaningful relationship between flexibility and internal process perspective.

4-4) There is a meaningful relationship between flexibility and learning and growth perspective.

Based on the above relations, the hypotheses were tested by Pearson correlation as shown in Table 5.
Based on the results of statistical tests (Table 5) we can say that there is a significant relationship between the flexibility and financial, internal process. There is not a significant relationship between the flexibility and customer, learning and growth.

Table 4. Correlations test of section 3 hypotheses

\begin{tabular}{lll}
\hline & & Financial \\
\cline { 2 - 3 } & Pearson Correlation & $0.39^{* *}$ \\
Sig. (2-tailed) & 0.001 \\
$\mathrm{~N}$ & 1230 \\
& Customer \\
& Pearson Correlation & $0.44^{* *}$ \\
Sig. (2-tailed) & 0.072 \\
& $\mathrm{~N}$ & 1230 \\
& & Internal process \\
& Pearson Correlation & $0.51^{* *}$ \\
& Sig. (2-tailed) & 0.056 \\
& $\mathrm{~N}$ & 1230 \\
& & Learning and growth \\
& Pearson Correlation & $0.56^{* *}$ \\
& Sig. (2-tailed) & 0.061 \\
$\mathrm{~N}$ & 1230 \\
& $* *$ indicate statistical significance at the .01 level \\
\hline
\end{tabular}

Table 5. Correlations test of section 4 hypotheses

\begin{tabular}{|c|c|c|}
\hline & & Financial \\
\hline & Pearson Correlation & $0.55^{* *}$ \\
\hline & Sig. (2-tailed) & 0.06 \\
\hline & $\mathrm{N}$ & 1230 \\
\hline & & Customer \\
\hline & Pearson Correlation & $0.59^{* *}$ \\
\hline & Sig. (2-tailed) & 0.056 \\
\hline \multirow[t]{10}{*}{ Flexibility } & $\mathrm{N}$ & 1230 \\
\hline & & Internal process \\
\hline & Pearson Correlation & $0.29^{* *}$ \\
\hline & Sig. (2-tailed) & 0.09 \\
\hline & $\mathrm{N}$ & 1230 \\
\hline & & $\begin{array}{l}\text { Learning } \\
\text { growth }\end{array}$ \\
\hline & Pearson Correlation & $0.34^{* *}$ \\
\hline & Sig. (2-tailed) & 0.073 \\
\hline & $\mathrm{N}$ & 1230 \\
\hline & $\begin{array}{l}* * \text { indicate statistic } \\
.01 \text { level }\end{array}$ & significance at the \\
\hline
\end{tabular}

In the fifth section, we had these 5-1) There is a meaningful relationship hypotheses: between proportion and financial perspective. 
5-2) There is a meaningful relationship between proportion and customer perspective.

5-3) There is a meaningful relationship between proportion and internal process perspective.

5-5) There is a meaningful relationship between proportion and learning and growth perspective. Based on the above relations, the hypotheses were tested by Pearson correlation as shown in Table 6. Based on the results of statistical tests (Table 6) we can say that there is a significant relationship between the proportion and Financial. There is no significant relationship between the proportion and other dimensionss of the performance (customer, internal process, learning and growth).
In the sixth section, we had these hypotheses:

6-1) There is a meaningful relationship between implementation and financial perspective.

6-2) There is a meaningful relationship between implementation and customer perspective.

6-3) There is a meaningful relationship between implementation and internal process perspective.

6-4) There is a meaningful relationship between implementation and learning and growth perspective.

Based on the above relations, the hypotheses were tested by Pearson correlation as shown in Table 7.

Table 6. Correlations test of section 5 hypotheses

\begin{tabular}{lll}
\hline Proportion & \multicolumn{1}{c}{ Financial } \\
\cline { 2 - 3 } & Pearson Correlation & $0.62^{* *}$ \\
Sig. (2-tailed) & 0.001 \\
$\mathrm{~N}$ & 1230 \\
& Customer \\
& Pearson Correlation & $0.44^{* *}$ \\
Sig. (2-tailed) & 0.073 \\
$\mathrm{~N}$ & 1230 \\
& Internal process \\
& Pearson Correlation & $0.42^{* *}$ \\
Sig. (2-tailed) & 0.078 \\
N & 1230 \\
& Learning and growth \\
& Pearson Correlation & $0.36^{* *}$ \\
Sig. (2-tailed) & 0.078 \\
N & 1230 \\
& level indicate statistical significance at the .01 \\
& \\
\hline
\end{tabular}

Table 7. Correlations test of section 6 hypotheses 


\begin{tabular}{lll}
\hline & & Financial \\
\cline { 2 - 3 } & Pearson Correlation & $0.68^{* *}$ \\
& Sig. (2-tailed) & 0.002 \\
& $\mathrm{~N}$ & 1230 \\
& Pearson Correlation & Customer \\
& $0.32^{* *}$ \\
Implementation & Sig. (2-tailed) & 0.070 \\
& $\mathrm{~N}$ & 1230 \\
& & Internal process \\
& Pearson Correlation & $0.41^{* *}$ \\
& Sig. (2-tailed) & 0.073 \\
& & 1230 \\
& Pearson Correlation & Learning and growth \\
& Sig. (2-tailed) & 0.009 \\
& N & 1230 \\
& $* *$ indicate statistical significance at the .01 \\
& level & \\
\hline
\end{tabular}

Based on the results of statistical tests (Table 7) we can say that there is a significant relationship between the implementation and financial, learning and growth. There is no significant relationship between the implementation and customer, internal process.

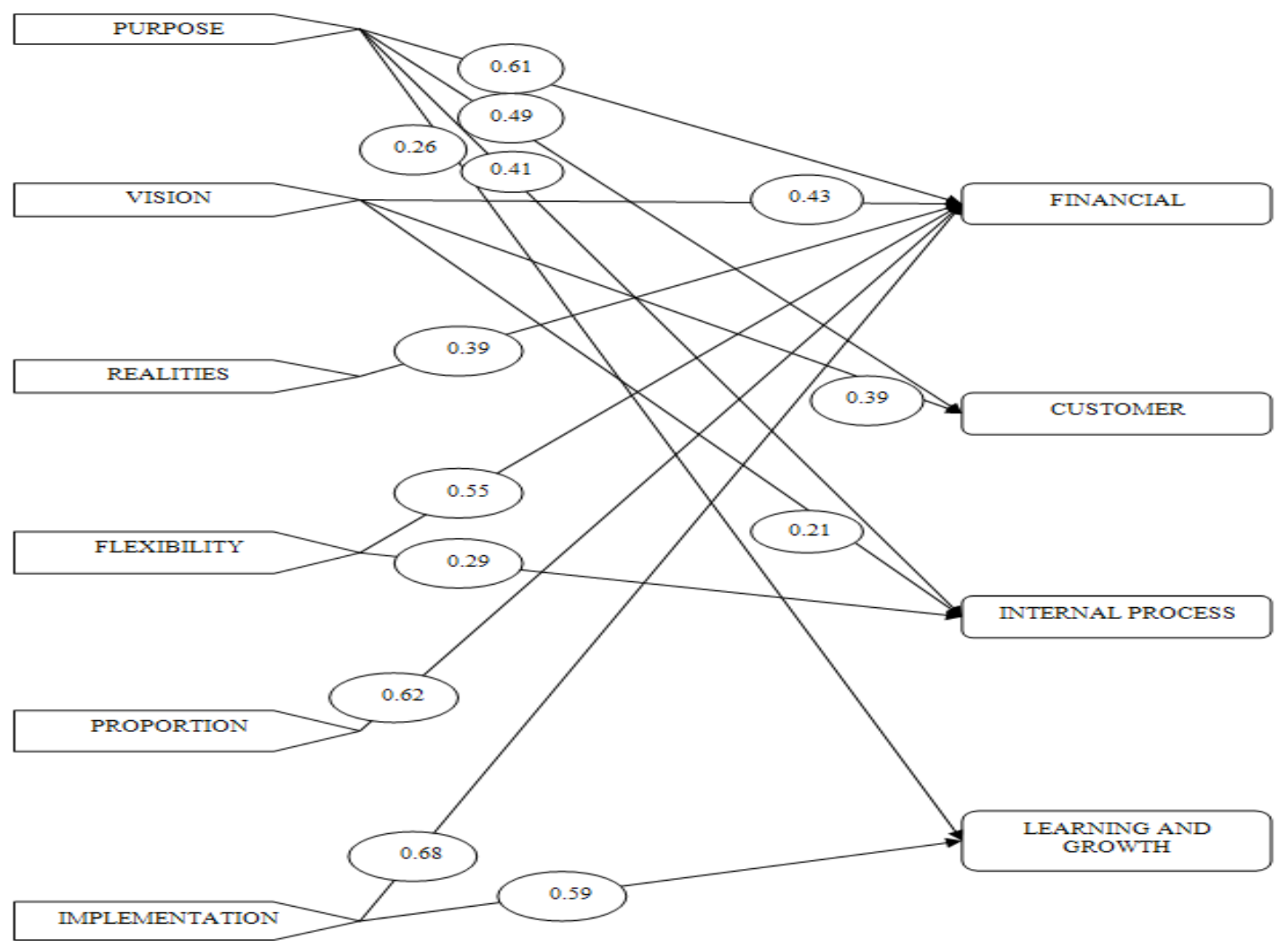

Figure 6. Result of all hypotheses

Also, Figure 6 shows the results of all hypotheses. 
Table 8. Summaries the all of the above results

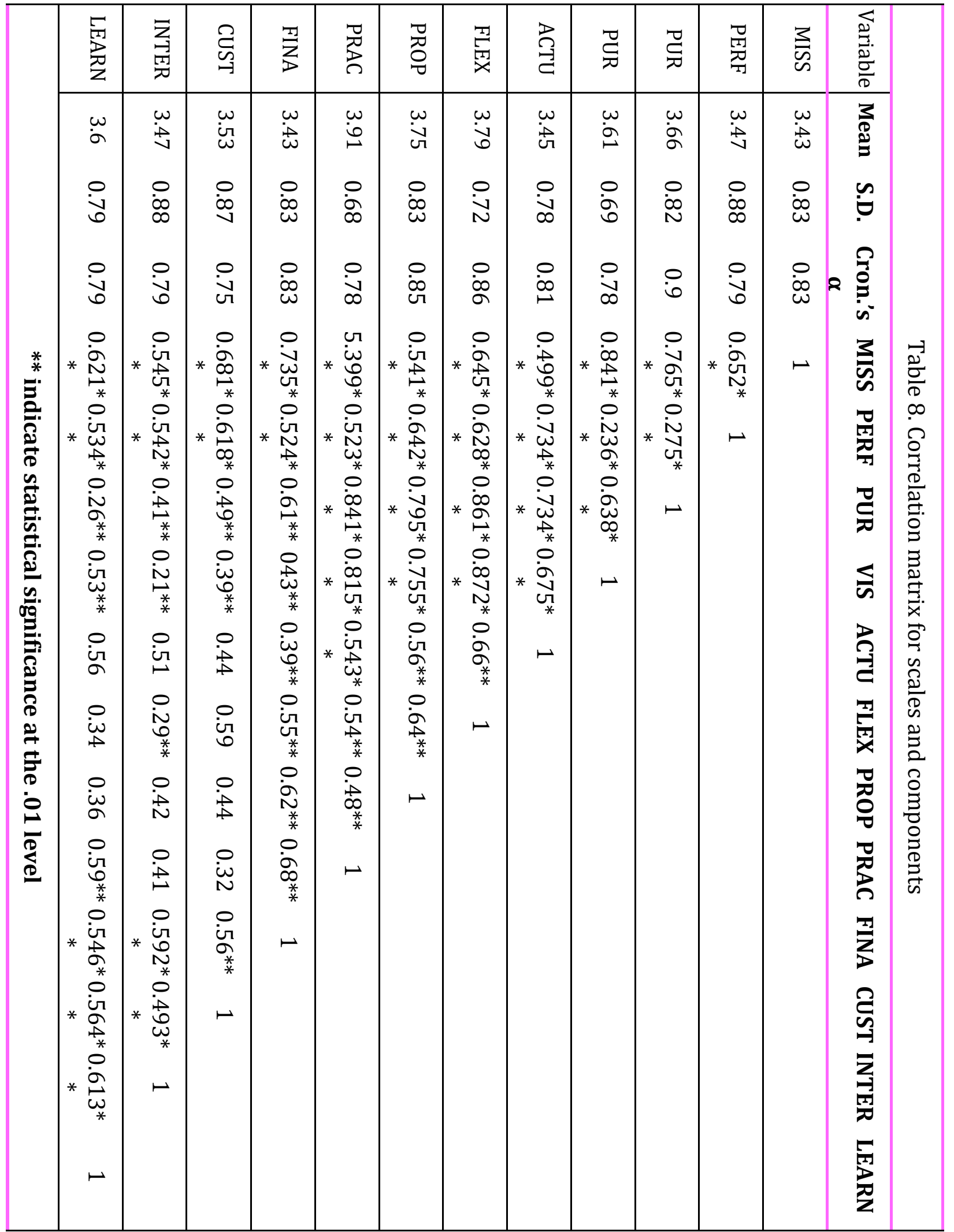




\section{Discussion}

As found from the data analysis, the purpose is associated whit four dimensions of the BSC (financial, customer, internal process, learning and growing). The vision was connected to three dimensions of the BSC (financial, customer, internal process). There are relationships between the realities and one dimensions (financial). The flexibility was connected to two dimensions of BSC (financial, internal process). Proportion is associated with one dimension of the BSC (financial). Finally, there are relationships between the implementation and two dimensions (financial, learning and growing). Results indicate that there is the most significant positive relationship between the purpose and the financial components and there is the least significant positive relationship between the vision and the internal presses. It means the purpose components have the most important role in the performance compared with other components of the mission statement, and the vision component has the least importance in the performance compared with other components in the mission statement.

\section{Conclusion}

The strategic planning process calls for careful development of a firm mission statement (Green and Medlin, 2003). The mission statement is the vital for firms' success. If the mission statement is complete, it could positively affect on the firm's performance. In this paper, relationship between the components of the mission statement and the components of performance in firms in which the BSC strategy was developed was investigated. The study results indicate that there is no positive relation between all of the mission statement components and the BSC dimensions in the performance evaluation.
Among the relationships, there is the most significant positive relationship between the purpose and the financial components , and there is the least significant positive relationship between the vision and the internal presses. It is important to note that all of the mission statement components were connected with four of the dimensions of the BSC in the performance evaluation. This result was confirmed by Darbi (2012); Alavi and Karami (2009); Bart and Hupfer (2004); Bart and Baetz (1998); Bart and Tabone (1998) that the components of the mission statement have direct affection on the finance. Finally, the mission statement components have a vital role in the finance performance. Based on the study results, the following recommendations are presented:

- A mission statement is developed based on the current action in firm;

- A mission statement must be implementable;

$\diamond$ A mission statement should have ability for destruction;

$\diamond$ The size and environment are cared by a mission statement;

- A mission statement is acceptable among manager and employers;

$\times$ A mission statement is presented as important tools for communicating the mission to internal and external stakeholders.

\section{References}

Agostino, D, Arnaboldi, M. (2011). How the BSC implementation process shapes its outcome, International Journal of Productivity and Performance Management, 60(2): 99-114.

Alavi, M.T, Karami, A. (2009). Managers of small and medium enterprises: mission statement and enhanced organisational 
performance, Journal of Management Development, 28(6): 555-562.

Alison, K, Kaye, J. (2005). Strategic planning for nonprofit organization, New Jersi: John Wiley \& Sons.

Allen, R. S, Helms, M. M. (2002). Employee perceptions of the relationship between strategy, rewards and organizational performance, Journal of Business Strategies, 19(2): 115-139.

Analoui, F, Karami, A. (2002). CEOs and development of the meaningful mission statement, Corporate Governance, 2(3): 1320.

Barnes, J. L. (1987). An international study of curricular organizers for the study of technology, unpublished doctoral dissertation, Virginia Polytechnic Institute and State University: Blacksburg, Virginia.

Bart, C.K. (1998). A comparison of mission statement and their rationales in innovative and non-innovative firms, International Journal of Technology Management, 16(1): 64-77.

Bart, C.K, Baetz, M. (1998). The relationship between mission statements and firm performance: An exploratory study, Journal of Management Studies, 35: 823-826.

Bart, C.K, Hupfer, M. (2004). Mission statements in Canadian hospitals, Journal of Health Organization and Management, 18(2): 92-110.

Bart, C.K, Tabone, J. (1998). Mission statement content and hospital performance in the Canadian not-for-profit health care sector, Health Care Manager, 24(3): 108-116.
Bryson, J. M, Alston, F.K. (2005). Creating and implementing your strategic plan, San Francisco: Jossy-bass.

Campbell, D, Shrives, P, Bohmbach, H. (2001). Voluntary disclosure of mission statements in corporate annual reports: signaling what and to whom?, Business and Society Review, 106(1): 89-115.

Collins, J.C, Porras, J.I. (1997). Built to Last: Successful Habits of Visionary Companies, New York: Harper-Collins.

Crossan, M, Bedrow, I. (2003). Organizational learning and strategic renewal, Strategic Management Journal, 24: 1087-1105.

Darbi, W.P.K. (2012). How do highperforming organizations define their mission in Ghana?, African Journal of Economic and Management Studies, 3(2): 184-204.

Desmidt, S, Prinzie, A, Decramer, A. (2011). Looking for the value of mission statements: a meta-analysis of 20 years of research, Management Decision, 49(3): 468-483.

Drohan, W. (1999). Writing a mission statement, Association Management, 51: 117-126.

Egormen, C, Doran, R. (1999). Mission statements in small and medium sized businesses, Small Business Management, 37(4): 59-66.

Haghighy, M, Gharleghi, E, Mirasadi, S, Nikbakht, F. (2010). A survey of relationship between the characteristics of mission statement and organizational performance, A study of Change Management, 4: 36-47.

Hahn, W, Powers, T. (1999). The impact of strategic planning sophistication and 
implementation on firm performance, The Journal of Business and Economic Studies, 5(2):: 19-35.

Kaplan, R.S, Norton, D.P. (2001). The Strategy-Focused Organization: How Balanced Scorecard Companies Thrive in the New Business Environment, Boston: Harvard Business School Press.

Green, K. W, Medlin, B. (2003). The strategic planning process: the link between mission statement and organizational performance, Academy of strategic management journal, 2: 23-31.

Klemm, M, Sanderson, S, Luffman, G. (1991). Mission statement: Selling corporate values to employees, Long Range Planning, 24( 3): 73-79.
Niven, R. (2008). Balanced scorecared stepby-step for government and nonprofit agencies, New Jersi:John Wiley \& Sons.

Pearce, J. (1982). The company mission as a strategic tool, Sloan Management Review, 23(3): 15-24.

Toftoy, C, Chatterjee, J. (2004). Mission statements and the small business, Business Strategy Review, 15(3): 41-44.

Wheelen, T.L, J.D, Hunger. (2000). Strategic Management, Upper Saddle River, New Jersey: Prentice-Hall.

Wilson, I. (1992). Realizing the power of strategic vision, Long Range Planning, 25(5), 18-28.

Wing, B. W, Guo, L, Li, W, Yang, D. (2007). Reducing conflict inbalanced scorecard evaluations, Organizations and Society, 32(4-5): 363-377.

How to cite this article: Sajjad Salehi-Kordabadi, Sajjad Karimi, Mohammad Qorbani-Azar, The Relationship between Mission Statement and Firms' Performance. International Journal of Advanced Studies in Humanities and Social Science, 2020, 9(1), 21-36. http://www.ijashss.com/article 105612.html 